Volume 3, Issue 2, 247-262, 2009

\title{
Teaching For and About Critical Pedagogy in the Post-Secondary Classroom
}

\author{
MARY BREUNIG \\ Recreation and Leisure Studies, Brock University, St. Catharines, Canada
}

\begin{abstract}
While there is a body of literature that considers the theory of critical pedagogy, there is significantly less literature that specifically addresses the ways in which professors attempt to apply this theory in practice. This paper presents the results from a study that was designed, in part, to address this gap. Seventeen self-identified critical pedagogues participated in this qualitative research study. Participants reported their use of the following classroom practices, including: dialogue; group work; co-construction of syllabus; and experiential activities. This paper critically examines the social justice-oriented nature of these critical classroom practices.
\end{abstract}

\section{Introduction}

As a self-identified critical pedagogue teaching courses on critical pedagogy and experiential education at a Canadian university, students in my courses are often impelled to consider the justice-oriented nature of the theory of critical pedagogy. While the course content for many of these classes introduces students to critical pedagogical theory, the class structure itself has often been quite traditional. A typical class meets twice a week for 1 hour and 20 minutes each session; on most days, the students read an article or a series of articles, many of these written by a number of influential educational pedagogues, including: bell hooks, Patti Later, Henry Giroux, Roger Simon, Ira Shor, Deborah Britzman, Paulo Freire, Donna Haraway, and Michael Apple, to name a few.

When teaching students about critical pedagogy, I have tended to adopt a fairly didactic method of teaching. On occasion, I present an activity that relates to the topic. Over time, I have become increasingly concerned about the gap between what I teach and believe and my pedagogical practice, how I teach. More recently, the students in my classes and I have been talking about the ways in which we could engage in both classroom and out-of classroom experiences that would be more justice-oriented. More specifically, I am interested in how to develop a more 
purposeful classroom practice that acts on the theoretical underpinnings of critical pedagogy.

This present study developed, in part, out of this lived experience. How do professors who teach critical social theory and critical pedagogy attempt to practice it within the post-secondary classroom? I wonder about the degree to which professors' pedagogical approaches correspond with their critical curricula. These queries led me to this present study which explores the successes and challenges that critical pedagogues encounter as they endeavour to turn the theories of critical pedagogy into post-secondary classroom practices.

While there is a body of literature that considers the theory of critical pedagogy, Ira Shor (1996) and Stephen Sweet (1998), among others, assert that there is less literature that specifically addresses the ways in which professors attempt to apply this theory in practice. Jennifer Gore (1993) argues that, in fact, some of the best writings of critical theorists offer little suggestion of strategies that teachers might use in practice. Furthermore, many of these theorists provide too little explication of what attempts are made within these educators' own classrooms to implement the critical pedagogy that they espouse (Keesing-Styles, 2003). These arguments, in essence, represent a "call to action" for those professors who teach about critical pedagogy to continue to examine their own classroom practices.

The purpose of this paper is to present some of the key findings from a qualitative research study which explored the ways in which 17 self-identified critical pedagogues actually engage in critical pedagogical praxis within the post-secondary classroom. Specifically, this paper will focus on presenting examples of effective critical classroom practices that arose as a result of this study. It will additionally examine the justice-oriented nature of some of the reported examples of practice.

\section{Critical Pedagogy}

There are multiple and varied definitions of critical pedagogy (see Table 1 below). Many of these definitions centre around some of the influential critical theorists. For example, the critical theoretical tradition developed by the Frankfurt School was greatly influenced by the work of Karl Marx, particularly his views about labour. According to Marx, the essential societal problem was socioeconomic difference. Marx believed that all people needed to work toward a socialized economy within which each individual received according to her needs and contributed according to her ability (Eisner, 2002). In essence, Marx argued that social justice is dependent upon economic conditions.

In the late 1970s and 1980s, the "New Left Scholars" including Henry Giroux Roger Simon, Michael Apple, and Peter McLaren began to focus their efforts on examining and better understanding the role that schools play in transmitting certain messages about political, social, and economic life believing that a revolutionary critical pedagogy will allow educators to realize the possibilities of democratic social values within their classroom (Kincheloe, 2004).

The critical theory of the "New Left" was politically influenced by the anticolonial liberation movements breaking out in Africa, Asia, and perhaps most notably Latin America (Kincheloe, 2004). One of the key figures in the Latin 
American liberation movement was Paulo Freire, who is commonly regarded as the inaugural philosopher of critical pedagogy (McLaren, 2000). Freire's work with the poor in Brazil introduced him to the lives of impoverished peasants. His experiences compelled him to develop educational ideals and practices that would serve to improve the lives of these marginalized people and to lessen their oppression. Freire's (1970) problem-posing model of education valued the importance of student experience and a dialogical method of teaching and learning whereby the student and the teacher were mutually engaged in the production of knowledge and the process of teaching and learning.

A more present day conception of critical pedagogy examines the influence of the postdiscourses (e.g. poststructuralism and postcolonialism) on theory and praxis (Kincheloe, 2004). Patti Lather's work in the field of critical education has revolved around characterizing the relationship between feminist and critical pedagogy, feminist ethnography, and poststructuralism (Kincheloe, 2004). Lather (1991) examines the ways in which many of the postdiscourses can help critical pedagogues explore and critique the role of power and hegemony in research methods and modes of knowledge production.

Caroline Shrewsbury (1987), bell hooks (1994), and Kathleen Weiler (2001), alongside other feminist pedagogues, argue that education should serve to challenge the structure of the traditional canon and should develop and offer alternative classroom practices. Feminist pedagogy reinforces the idea that both the content of the curriculum and the methods of pedagogy employed teach lessons.

Table 1. Overview of Historical Roots—Critical Pedagogy

\begin{tabular}{|c|c|c|c|c|c|}
\hline $\begin{array}{l}\text { Critical } \\
\text { Social } \\
\text { Theorists- } \\
\text { social and } \\
\text { economic } \\
\text { equality }\end{array}$ & $\begin{array}{l}\text { Liberatory } \\
\text { Education } \\
\text { emancipation } \\
\text { from } \\
\text { oppression }\end{array}$ & $\begin{array}{l}\text { Pedagogical } \\
\text { Project of } \\
\text { Possibility- } \\
\text { disrupting the } \\
\text { dominant } \\
\text { (socioeconomic } \\
\text { privileged) } \\
\text { discourse }\end{array}$ & $\begin{array}{l}\text { Feminist } \\
\text { Pedagogy } \\
\text { disrupting } \\
\text { the } \\
\text { dominant } \\
\text { (male } \\
\text { privileged) } \\
\text { discourse }\end{array}$ & $\begin{array}{l}\text { Post- } \\
\text { structuralism } \\
\text { multiple } \\
\text { "ways of } \\
\text { knowing” that } \\
\text { are situated, } \\
\text { contextual, } \\
\text { and partial }\end{array}$ & $\begin{array}{l}\text { The } \\
\text { Possibility of } \\
\text { Pedagogical } \\
\text { Practice- } \\
\text { employing the } \\
\text { theory of } \\
\text { critical } \\
\text { pedagogy in } \\
\text { praxis }\end{array}$ \\
\hline $\begin{array}{l}\text { Max } \\
\text { Horkheimer }\end{array}$ & Paulo Freire & Henry Giroux & bell hooks & Patti Lather & Paulo Freire \\
\hline $\begin{array}{l}\text { Theodor } \\
\text { Adorno }\end{array}$ & & $\begin{array}{l}\text { Peter McLaren } \\
\text { (cultural } \\
\text { studies) }\end{array}$ & $\begin{array}{l}\text { Caroline } \\
\text { Shrewsbury }\end{array}$ & $\begin{array}{l}\text { Donna } \\
\text { Haraway }\end{array}$ & Ira Shor \\
\hline \multirow[t]{2}{*}{$\begin{array}{l}\text { Herbert } \\
\text { Marcuse }\end{array}$} & & $\begin{array}{l}\text { Michael Apple } \\
\text { (curriculum } \\
\text { studies) }\end{array}$ & $\begin{array}{l}\text { Kathleen } \\
\text { Weiler }\end{array}$ & $\begin{array}{l}\text { Deborah } \\
\text { Britzman }\end{array}$ & \\
\hline & & Roger Simon & & & \\
\hline
\end{tabular}

Despite the fact that Table 1 (above) may represent an oversimplification of many aspects of the historical roots of critical pedagogy, it does provide one way to view some of the pedagogies that are central to this review of literature. Within this abridged "history," there is contradiction, overlap, and resistance to the attempts of 
some critical theorists and pedagogues to identify the "one perfect" definition or a narrow set of prescriptive practices that constitute the field of critical pedagogy. Some of this contradiction and overlap centers around an approach to critical pedagogy that adopts a positive, revolutionary utopian approach (Britzman, Freire, Giroux, hooks, McLaren, Shor) versus a negatively critical approach (Gur-Ze'ev). Each approach offers both possibilities and limits.

Despite these varied conceptions of critical pedagogy and the multiple and varied definitions, there seems to be some congruence between them. Essentially, the intent of critical pedagogy is to contribute to a more socially just world (Kanpol 1999; Keesing-Styles, 2003; Kincheloe, 2004). This definition is the one that will be employed throughout this paper. The term social justice is one that will be employed throughout this paper as well. Historically (and and in its simplest conception), social justice is the attainment of equality in every aspect of society (Atkinson, 1982). It is a philosophical and ideological construct - one that examines a multiplicity of issues pertaining to egalitarianism (e.g. economic, religious, political, gender, age, etc) (Atkinson). For many contemporary justice-oriented theorists and pedagogues, social action is a key and necessary component of this concept (Kolmuss \& Agyeman, 2002; O’Donoughue \& Lotz-Sisitka, 2002; Prilleltensky, 2001).

\section{Critical Pedagogical Praxis}

The above definitions and abridged historical overview provide a theoretical foundation of critical pedagogy and social justice. Yet, the mere transmission of theoretical knowledge about these concepts does not ensure that students are acting upon the justice-oriented intentions that the theory purports. Theory needs to be connected to practical, lived experiences both outside and within the classroom (Van Manen, 1999). There is clearly a responsibility on the part of the teacher to create appropriate classroom strategies and practices that incorporate the theoretical insights of critical pedagogy and that are appropriate for the particular classroom context (Keesing-Styles, 2003).

As Keesing-Styles suggests, however, "[t]his is not to say that specific 'recipes' for educative practice are required" (p. 6). Rather, classroom practices need to be shaped around the lives of students, the classroom context, the educative aims of the practice, and the institution to construct learning experiences that articulate these.

While the majority of writing to date has focused on theoretical knowledge, there have been a few studies conducted which offer insight into the theory/practice relationship. Beatriz Ruiz and Juan-Miguel Fernandez-Balboa (2005), and Doune Macdonald and Ross Brooker (1999), both examined physical education teacher educators' critical pedagogical praxis. They concluded that many of their study participants reverted back to the type of transmission-based pedagogy they knew best from their own formal school experiences because these professors lacked concrete examples of how to engage in critical praxis (Ruiz \& Fernandez-Balboa, 2005). Macdonald and Brooker (1999) discovered that there was a need for more explicit information regarding how educators can employ critical pedagogical praxis within the post-secondary classroom. 
In Finding Oneself in the Classroom: A Critical Autoethnographic Narrative Chronicling the Risks and Rewards of a Teacher and Her Students as They Engage in the Practice of Critical Pedagogy" Nancy Horan (2004) identified some of the successes and challenges that she and her students experienced when attempting to put the theory of critical pedagogy into practice. In When Students Have Power: Negotiating Authority in a Critical Pedagogy, Shor (1996) discusses his experiences with trying to engage in critical praxis in his Utopia course, highlighting the successes, challenges and lessons learned by both him and his students when trying to practice critical pedagogy. Wink (2005), in a somewhat similar vein, wrote about her attempts to implement critical pedagogy. Critical Pedagogy: Notes from the Real World (Wink, 2005) is, in my view, part critical pedagogy primer and part manual for practicing critical pedagogy. For example, in her sixth chapter, entitled "How in the World Do you Do it?," she enumerates many examples of how to apply the theory of critical pedagogy within the university classroom.

In addition, there is a body of literature that examines praxis-oriented teacher education across various contexts. Shauna Butterwick and Jan Selman (2003) investigated the ways in which popular theatre, with its creative approach to naming and acting on problems, provided an opportunity for study participants to gain insights into issues related to social justice and the value of participatory and democratic classroom processes. Academic service-learning combines academic study with community service (Eyler \& Giles, 1999). Service-learning can provide students with an opportunity to engage in an experiential, hands-on activity that helps them examine and modify their often prejudicial attitudes toward race, class and economic injustices (Green, 2001). A number of studies have examined the ways in which students often change their attitudes toward themselves and the community as a result of engaging in service-learning projects (Boyle-Baise \& Kilbane, 2000; Green, 2001).

Critical media literacy represents another example of a praxis-oriented activity. The intent of critical media literacy is to emancipate students' worldview and for students to engage in transformational social action (Hull, 1993). Numerous studies have examined the ways in which these praxis-oriented forms of pedagogy can be used as a means to link what goes on in the classroom with what goes on in society (McLaren \& Farahmandpur, 1999; Norton-Meiers, 2002).

These studies, books, and examples provide some insights into the theory/practice relationship within post-secondary classrooms. This study was designed to expand upon that information and to respond to the "call to action" within the literature (Keesing-Styles, 2003; Lusted, 1986; McLaren, 2003; Shor, 1992; 1996) imploring critical pedagogues to begin to more fully integrate the ideal of the theory of critical pedagogy with a classroom praxis that is congruent with that theory.

\section{Methodology}

The following key query guided the research study: What are the ways in which selfidentified critical pedagogues actually engage in critical pedagogical practices within the post-secondary classroom? This section will outline the research participants, materials, and the research design for this study. 


\section{Participants}

I sent out several "calls" for research participants to the listserv of the Critical Educators for Social Justice Special Interest Group (CESJ-SIG) of the American Educational Research Association (AERA) in September, 2005 to recruit selfidentified critical pedagogues who were interested in participating in this study. In total, there were 17 self-identified critical pedagogues from that group who participated in this study. Of those 17 people, ten were female and seven were male. There was a wide age range, with one participant being between the ages of 30-40 and one participant being over 70 years old. Most participants were between the ages of 50-60. Ten participants were non-tenured professors and one of these was a fulltime lecturer and doctoral student. Seven participants were tenured professors.

Thirteen participants self-identified themselves as Caucasian; one as Latina; one as Native-American; one as Chicana; and one as Asian American. Two research participants were Canadians, teaching in Canadian universities and the rest (15) were from the United States, teaching in universities in the United States.

Participants were made aware of the nature of this study, their role in it, provisions for confidentiality, and their option to withdraw from the study at any point. Signed informed consent was obtained prior to the collection of data. Participants' names were changed for the purposes of anonymity and pseudonyms are used within the Results section of this paper.

\section{Materials}

I conducted phone interviews with the 17 participants between October, 2005 and February, 2006. The length of each interview varied only slightly, each one lasting approximately one hour. The interviews were semistandardized (Berg, 2004). The value of this form of "less structured" interview was that it allowed for opportunities for exploration of areas that I had not previously considered (Reinharz, 1992).

As previously mentioned, the specific purpose of this paper is to present some of the key findings related to examples of effective critical classroom practices that arose from a larger qualitative research study which explored the ways in which 17 self-identified critical pedagogues actually engage in critical pedagogical praxis within the post-secondary classroom. The initial interview queries included questions about critical pedagogy definitions, aims and purposes. Although this paper will not present all of the results related to those responses, they will be briefly mentioned next in order to highlight some of the diversity within the group as it related to selfidentification.

Eight study participants mentioned that their teaching focused on social justice, employing terms such as emancipation and/or transformation, social consciousness and activism, and social change. Five participants responded to the interview queries related to definition and central aims of critical pedagogy using terms that suggested a more student-centred or constructivist orientation, employing terms such as critical thinking, profound learning experiences, and student-centredness. Three participants self-identified as Freirean pedagogues and one participant said that he was a social reconstructionist. 
Because this paper focuses on classroom praxis, the list of guiding questions specifically related to that aspect of the study consisted of a small set of queries lifted from a larger set of interview questions from the study as a whole. The questions were: Do you believe that you engage in classroom practices that reflect the theories of critical pedagogy? What are some examples of your classroom practices that reflect the ways in which you employ critical pedagogy?

\section{Design}

The study employed Appreciative Inquiry (AI) as the methodological framework. AI involves the art and practice of asking questions that strengthen either a system's or a person's capacity to apprehend, anticipate, and heighten positive potential (Cooperrider, Whitney \& Stavros, 2003). It seeks to build upon achievements, unexplored potential, innovations, strengths, competencies, stories, lived values, traditions, and visions. Taking all of these together, AI seeks to link these positive insights directly to a change agenda (Cooperrider, Whitney \& Stavros, 2003).

\section{Data Analysis}

All 17 interviews were transcribed by a transcriber. I sent a copy of the transcripts back to each interview participant for his or her review. The process of data analysis was guided by the main objective of the study and by the review of related literature. I thus began data analysis by establishing some initial categories and themes related to the objectives and the literature. I next read through all of the transcriptions in the spirit that Berg (2004) suggests- “as a passport to listening to the words of the text and understanding better the perspective(s) of the producer of these words” (p. 269). I read through the transcriptions with a view to identify other categories and themes that emerged out of participants' responses to the interview questions.

\section{Results and Discussion}

The Results and Discussion section will integrate the findings from this study with the critical pedagogy literature that examines theories and practices. This section will focus on presenting examples of effective critical classroom practices that arose as a result of this study. It will additionally examine the justice-oriented nature of some of the reported examples of practice, critiquing some of the claims made by participants.

The critical query that will be explored in this next section will be: Are the examples cited within the results of this study truly congruent with the justiceoriented nature of the theory of critical pedagogy? The conclusions drawn here are those that emerged out of an analysis of participant responses. This next section therefore includes select quotes and paraphrases with relevant literature integrated.

The following classroom practices emerged as central themes: classroom community and group work; dialogue; curriculum negotiation, and assessment and evaluation; experiential activities; and "traditional" classroom practices. These 
themes will be highlighted and discussed within this next section. Surprisingly, there were few results that could be attributed to some of the differences in participant demographics. In other words, differences in age and gender, among others, did not factor into the results in any significant way and are thus not discussed in this next section.

\section{Classroom Community and Group Work}

Many interview participants responded that building a classroom community was one of the central features of their critical praxis within the post-secondary classroom. For example, Bailey commented on how she tries to "create a really safe and comfortable space for students to talk and to process their own stuff. I also do a ton of sharing of my own stories.” Taylor said that:

[I] try to create a safe space where students will feel comfortable, expressing where they're at and moving from there. I just ask that they be open to other ways as well and we spend a lot of time every semester engaged in basically community building.

Participants additionally reported about the importance and value of group work, and this classroom practice was often closely linked with the practice of dialogue. Graham said that he asks students to complete an assigned reading and then asks them to break out into groups and prepare questions. He said that students then, "[d]iscuss the readings in small groups during class time. They then come back into a large group and see what the consensus was around the reading and the topic." Bailey said that she uses "think-pair-share" as a group work technique, whereby a student first individually works on a particular question or problem and then pairs up with another person to problem solve and explore the question; that pair then finds another pair or two and continues to brainstorm, synthesizing the various responses that have resulted from this "think-pair-share" experience to formulate a response.

The concept of building a classroom community and employing collaborative learning techniques, including small group work and activities similar to "think-pairshare" (Lyman, 1981) have been widely researched and advocated throughout educational literature (Bruner, 1996; Gokhale, 1995; McKeachie, Pintrich, Lin, Smith, \& Sharma, 2000). For example, Anurhadha Gokhale (1995) examined the effectiveness of individual learning versus collaborative learning in enhancing the critical thinking skills of 48 university students using a pretest/posttest questionnaire and found that students who participated in collaborative learning performed significantly better on the critical-thinking test than students who studied individually.

According to Felder and Brent (1996), student-centred instruction involving active learning, student involvement, experiential activities, and cooperative learning led to increased motivation to learn. Even with students in large classes (between 200-300 students), using techniques such as group work and peer assessment resulted in students having a more positive response to class, attending class more often, and developing effective learning strategies (Scott, Buchanan, \& Haigh, 1997). 
This research on student-centred and constructivist-oriented classroom practices leads me back to my query regarding the critical (or justice-oriented) nature of these forms of praxis. If students are engaged with content and are motivated to learn through constructivist approaches (Felder \& Brent, 1996; Meyers \& Jones, 1993), but there is no explicit communication of the ways in which these practices can be used as a means to bring about a more socially just world, then critical pedagogues (at least those participants in this study) may not be fulfilling the goals of the justiceoriented and liberatory nature of critical pedagogical praxis per se. However, the value in this form of praxis cannot be too quickly discounted. Creating a democratic space in the classroom through student-centred and constructivst-oriented classroom practices can be an act of social justice itself (Dewey, 1938), particularly in schools and classrooms where these practices are counterhegemonic and anti-oppressive (Shor \& Pari, 2000).

\section{Dialogue}

Dialogue was another central theme that arose as a result of participants' reports about their critical pedagogical praxis. Bob talked about the importance of group work and group discussion within the classroom, but he also highlighted the value of what he referred to as a dialogue journal. For Bob, the use of a dialogue journal provides students with an opportunity to reflect on their learning throughout the semester. Meg talked about the ways in which she combines computer technology with dialogue. She said:

\footnotetext{
I use the Blackboard System [an online forum] a lot. I'll post a discussion question and then, what I did this year was, I made all the students in the class teaching assistants in the class which allowed them to post their own questions and generate forums for discussion themselves. So I'm not always guiding that.
}

Although there exists some evidence that using dialogue to engage student voices can enhance learning (Jarvis, 1996) and impel students to reconceptualize “traditional” power relations (Lather, 1991; Shor, 1996), others would argue that the notion of liberatory dialogue and authentic voice represent a repressive myth in the field of critical pedagogy (Ellsworth, 1992; Gore, 1993; hooks, 1994; Luke, 1992).

Gur-Ze'ev (1998) claims that often critical pedagogues fail to more fully examine their use of dialogue and voice alongside the broader issues of who gets heard, what gets said, and who has authority, asserting that professors start with a critical selfexamination of their own practices. Dialogue thus conceived may attend to the justice orientation of a critical pedagogical praxis but the results from my study did not reveal the justice-oriented nature of this praxis; rather, participants focused on the value of this praxis as a form of student-centred learning and teaching.

\section{Assessment and Evaluation}

Participants said they also regarded their use of alternative methods of assessment and evaluation as critical in many respects. Examples of these alternative methods 
included: co-designing assignments and rubrics; self and peer assessment; contract grading; and the use of portfolios.

For example, Jack talked about how students must prepare their final assignment in his "Ethics and Equity in Education" course. They have to prepare a paper as though they are going to give a presentation to the school board. They have to articulate an ethical position around what I would call the intrinsic morality of learning that is being ignored under the current school reform efforts.

Eleven research participants reported about the ways in which students coconstruct the course syllabus and negotiate the curriculum within the critical pedagogical classroom. Bob talked about how he predetermines some of the assignments and includes those on the initial course syllabi but leaves some opportunity for assignments to be co-determined by the class as a whole once the course is underway.

A number of people talked about their use of self- and peer-assessment, providing feedback on assignments without grading them, offering assignment rewrites, and trying to develop assessment tools that foster knowledge acquisition and critical thinking more than competition, including contract grading. For example, Meg said, "What I decided to do this year was to have students do individual learning contracts, rather than come up with a specific set of assignments or something that I would just impose on everybody."

According to reports, negotiating the curriculum (Bob, Donna, and Meg), developing rubrics (Anne, Bailey, and Nancy) co-designing the syllabus (Bob, Linda, Tom, Mark, Meg, and Sam) and self- and peer-assessment (Bailey, Catherine, and Sarah) were examples of classroom practices. According to participants, students felt more engaged with the learning process and thus attended classes more often and produced work that was of a higher quality.

Keesing-Styles (2000) and Tilemma (2003) affirm that assessment can serve as a powerful contributor to the learning process if students are empowered to participate in establishing the assessment criteria. Since assessment and evaluation have traditionally been the purview of the professor and one means for professors to maintain authority and power within the classroom (Shor, 1996), participants' reports related to their classroom practices provide some noteworthy counterhegemonic practices.

The above findings thus represent solid evidence of the value of student-centred and constructivist classroom practices but point less conclusively toward anything that could be identified as justice-oriented per se. Participants themselves alluded to this toward the end of their interviews. Interestingly, for example, Mark said that he believed that there may be much to be learned about justice without explicit instruction. As previously mentioned, Mark, in fact, said that often he will be deliberately less intentional about the social justice agenda of his teaching so that students, through group work, discussion, and written assignments, can come to that conclusion on their own. In this sense, Mark was asserting that a constructivist approach to learning may often be enough if the professor orients the curricula toward the purpose of social justice. 


\title{
Experiential Activities
}

Participants cited both on campus and off campus experiential activities that they employed within their post-secondary practices, echoing the sentiments of Peter McLaren and Donna Houston (2004) who assert that "critical pedagogy needs to flee the seminar room" (p. 36). These practices included: in class activities (including media literacy activities, role playing, and mock debates); community servicelearning and action research projects; and other experiential activities.

\section{In class experiential activities}

There were a number of in class experiential activities that participants reported. For example, Bailey talked about using an activity that she calls "take a stand." She described the practice:

\begin{abstract}
The students line up in a row and then they take two steps forward if they have a library in their home and one step backwards if they were bussed out of their neighbourhood to school and they respond to various questions like that and it inevitably stratifies the people in the room pretty much by class, race and gender.
\end{abstract}

Bailey said that she then facilitates a discussion about issues of oppression and privilege based on the students' experience with the "take a stand" activity. She reported that she has facilitated this activity in a number of different settings, including within the classroom and at conferences and she said that this activity always provokes conversation.

Bailey said that she will also ask students to take a survey, such as Peggy McIntosh's (1989) White Privilege Checklist, saying “I'll have them do the checklist and then write a reflection and then talk to a partner and share their reflections on their experience with having to list their privileges." She said that this helps students better understand some of the unearned privileges that many of them experience.

Jack said that he tries to "get people through a case study experience and asks them to role play some of the cases." He said he asks students to role play people in various positions of privilege within schools and those people in positions of less privilege.

Sam said that he asks students to draw an anatomy of an effective school leader as one example of an art-oriented experiential activity. He said that, "Students do drawings in small groups and I know when they've understood some of what I have been teaching when they come back with a head drawn with big ears and a small mouth." He said that in his view this demonstrates that students are able to comprehend some of the theory that he is teaching them.

\section{Community service-learning and/or action research projects}

Several study participants cited examples of community service-learning and action research projects as examples of post-secondary classroom practices. Anne talked about the ways in which she uses community service-learning to teach about critical pedagogy and issues of justice: 
In the past I had a teacher education class. It was a curriculum development course and I had my students create enrichment curricula for three homeless shelters. So they created this curriculum, using a Freirean approach. They had to interview the shelter residents and get to know them and find out what their whole day looked like and what interests they had. They then had to create evening enrichment activities for the shelter guests.

She said that another group of students conducted:

First person interviews with Vietnam veterans and listened to various speakers who served in Vietnam and then did some research and had to create curriculum related to the Vietnam War for the War Memorial in New Jersey for third grade students and fifth grade students based on their knowledge from these first person sources.

Anne said that both these experiences seemed to deeply enhance her students' understanding of issues of social justice, privilege, and oppression.

As previously mentioned in the literature review, academic service-learning combines academic study with community service (Eyler \& Giles, 1999) and requires students to apply theoretical knowledge to "real world" situations (Simons \& Cleary, 2005). Researchers have found that students often change their attitudes toward themselves and the community as a result of engaging in service-learning projects (Boyle-Baise \& Kilbane, 2000) and modify their perceptions regarding race, class, and economic injustices as a result of these service-learning activities (Green, 2001). Service-learning has come under some recent critique, however (Hesford, 2005). Hesford urges educators to more fully consider the intent of service-learning activities, in particular to ascertain how and whether particular programs actually counter and/or comply with exploitative practices (e.g. local/global labour practices). Recent research provides a counter argument to some of this critique however. According to Breunig (2005) and Jensen (2002), among others, the explicit articulation of the justice-oriented intent of an activity (e.g. service-learning) and the way in which it is facilitated significantly impacts and affects students' beliefs and actions about issues of justice, thus emphasizing the educative potential of a "well" and intentionally-facilitated activity.

Meg talked about an action research project that she does called "photovoice" whereby students take pictures of their communities (people, buildings, businesses, library, etc.) as a means to examine issues of hegemony. Laurie said that in her classes, students design a research project that examines a particular aspect of teaching and learning and conduct actual research in K-12 schools. Sam asks students to conduct a similar action research project.

Both Laurie and Sam have had students conduct research, write up their results, and occasionally present these projects as poster sessions at conferences. Donna has students read Dewey's books, Democracy and Education (1916) and Experience and Education (1938). She then asks student to consider the K-12 school context and asks them to try to identify and propose some changes that could be made within that system that would demonstrate some of the principles that Dewey presents in his 
books. Students engage in social action projects whereby they actually propose some of these changes to school administrators and local school boards.

Teaching about action research and the action research project itself can be dually oriented toward social change (Fletcher \& Coombs, 2004) and toward improving teacher practice. Given some of these responses and the relevant research (BoyleBaise \& Kilbane, 2000; Eyler \& Giles, 1999; Fletcher \& Coombs, 2004; Green, 2001), it is interesting, but perhaps not surprising, that participants cited so many examples of both community service projects and the numerous community-based action research projects that are components of their critical praxis.

In light of the above, the critical pedagogue who is employing this form of actionoriented praxis should provide both an activity and the appropriate facilitation, reflection, and justice-oriented content to help students consider and/or modify some of their previous prejudices. In other words, experience alone or "letting the experience speak for itself” may not be adequate.

\section{Other experiential activities}

Graham talked about the impact of other kinds of field activities, stating, "Well, I think taking the students out in the field is really it. Having them see that what I'm talking about isn't just theoretical and abstract, that poverty isn't an abstract issue or philosophic issue," for example, is really important. A number of study participants talked about the value of media literacy activities, as reported in the results. About half of the participants said that they bring in outside speakers or employ media literacy activities (e.g. analyzing films such as The Color of Fear (Mun Wah, 1994) and Crash (Haggis, 2004)) to teach students about justice-oriented issues.

Lori Norton-Meiers (2002) notes that the notion of films as visual texts worthy of academic study has been growing within the postsecondary academy for some time. Critical and media literacy activities can focus on developing students' ability not only to read and write, but also to critically assess texts and films in order to understand the relationships between power and domination that underlie and inform those texts (Hull, 1993). Ultimately, the intent of critical literacy is to emancipate students' worldview and for students to engage in transformational social action (Hull).

McLaren and Ramin Farahmandpur (1999) recommend that these praxis-oriented forms of pedagogy be utilized as a means to linking what goes on in the classroom with what goes on in society. The above action-oriented examples of classroom practices, alongside the review of related literature, suggest that these classroom practices can attend to the justice-oriented nature of a critical pedagogical praxis.

\section{Conclusion}

In reference to this study and in reference to some of the examples listed above, I now wonder if perhaps some participants engage in critical pedagogical praxis but their praxis represents an implicit approach to teaching and learning about issues of justice. If that is the case, can this implicit praxis still be called critical pedagogy? Mary Brewer (1999) argues, "There is little point in transforming our degree programs, revising the aims and objectives of courses or their content, or introducing 
new pedagogical discourses if our students do not know the purpose behind the changes” (p. 24).

It is clear that critical practices and classroom activities alone do not automatically or necessarily incite social justice and action (Keesing-Styles, 2003; Van Manen, 1999). In fact, there have been recent critiques of some critical pedagogical praxes asserting that these activities actually may hold miseducative potential (Hesford, 2005). Additionally, the burgeoning justice-oriented pedagogue ought to "mind the gap" between knowledge and attitudes and actions (Jensen, 2002; Kolmuss \& Agyeman, 2002; O’Donoghue \& Lotz-Sistika, 2002). The notion that justiceoriented praxes (e.g. environmental justice) are automatically educative (Russell, 1999) and the presupposition that knowledge and attitudes about justice lead to changed actions and behaviours may be a myth (O’Donoghue \& Lotz-Sisitka, 2002).

Perhaps then in light of the results from this study, there may be value for the selfidentified critical pedagogue to begin to develop strategies that explicitly and overtly address the justice-oriented nature that is purported by the theory of critical pedagogy. Additionally, critical pedagogues should be mindful about the facilitation of classroom activities and consider designing them in a manner that is congruent with the theory of critical pedagogy. One major limitation to this study is that I did not conduct follow-up interviews and thus was unable to explore some of these practices and facilitation techniques in more depth. Additionally, I was unable to further query participants about the potential gap(s) (those identified by participants themselves in the results of this study) between students' knowledge about critical theory and direct social action.

Future studies should explore this knowledge/action gap. Future studies should also focus on continuing to develop a set of "best practices" related to critical pedagogical praxis. There has been significant research to date regarding the value of student-centred and constructivist approaches to teaching and learning and less research to date regarding critical pedagogical praxis. For this reason, future studies should focus on encouraging self-identified critical pedagogues to articulate the ways in which their classroom practices do indeed attend to justice-oriented issues and should explore facilitation techniques alongside this.

In closing, both the participants in this study and the review of related literature seem to suggest that there may be a need for critical pedagogues to continue to broaden their understandings of the justice-oriented nature of critical praxis and to begin to articulate this intent more explicitly within their post-secondary classroom practices. This need is particularly true if the intent of critical pedagogical praxis is to contribute to a more socially just world (Kanpol, 1999; Keesing-Styles, 2003; Kincheloe, 2004).

\section{References}

Atkinson, A. B. (1982). Social justice and public policy. Boston, MA: MIT Press.

Berg, B. L. (2004). Qualitative research methods for the social sciences (5 ${ }^{\text {th }}$ ed.). Boston, MA: Pearson Education, Inc.

Boyle-Baise, M., \& Kilbane, J. (2000). What really happens? A look inside service-learning for multicultural teacher education. Michigan Journal of Community Service Learning, 7, 54-64.

Breunig, M. (2005). Turning experiential education and critical pedagogy theory into praxis. Journal of Experiential Education, 28(2), 106-122. 
Bruner, J. (1996). The culture of education. Cambridge, MA: Harvard University Press.

Brewer, M. (1999). Equal opportunities in higher education: The radical potential of student centered learning. Radical Teacher, 56, 19-25.

Butterwick, S., \& Selman, J. (2003). Deep listening in a feminist popular theatre project: Upsetting the position of audience in participatory education. Adult Education Quarterly, 54(1), 7-22.

Cooperrider, D. L., Whitney, D., \& Stavros, J. (2003). The appreciative inquiry handbook. Euclid, OH: Lakeshore Publisher.

Dewey, J. (1916). Democracy and education. New York, NY: Macmillan.

Dewey, J. (1938). Experience and education. New York, NY: Macmillan.

Eisner, E. (2002). The educational imagination: On the design and evaluation of school programs ( ${ }^{\text {rd }}$ ed.). New York, NY: Macmillan.

Ellsworth, E. (1992). Why doesn't this feel empowering? Working through the repressive myths of critical pedagogy. In C. Luke \& J. Gore (Eds.), Feminisms and critical pedagogy (pp. 90-119). New York, NY: Routledge.

Eyler, J. S., \& Giles, D. E. (1999). Where's the learning in service-learning? San Francisco: Jossey-Bass.

Felder, R. M., \& Brent, R. (1996). Navigating the bumpy road to student-centered instruction. College Teaching, 44, 43-47.

Fletcher, S., \& Coombs, S. (2004, November). Mentoring, action research and critical thinking scaffolds: Promoting and sustaining practitioner research through reflective practice. Paper presented at the Collaborative Action Research Network (CARN) Conference, Malaga, Spain.

Freire, P. (1970). Pedagogy of the oppressed. New York, NY: Continuum.

Gokhale, A. A. (1995). Collaborative learning enhances critical thinking. Journal of Technology Education, 7(1), 22-30.

Gore, J. M. (1993). The struggle for pedagogies: Critical and feminist discourses as regimes of truth. New York, NY: Routledge.

Green, A. E. (2001). "But you aren't white”: Racial perspectives and service learning. Michigan Journal of Community Service Learning, 8(10), 18-26.

Gur-Ze'ev, I. (1998). Toward a nonrepressive critical pedagogy. Educational Theory, 48(4), 463-486.

Haggis, P. (Director and Writer). (2004). Crash [Motion picture]. United States: The Writers Guild of America (WGA).

Hesford, W. S. (2005). Global/local labor politics and the promise of service-learning. In L. GrayRosendale \& S. Rosendale (Eds.), Radical relevance: Toward a scholarship of the whole left (pp. 183203). New York, NY: SUNY Press.

Hooks, B. (1994). Teaching to transgress: Education as the practice of freedom. New York, NY: Routledge.

Horan, N. L. (2004). Finding oneself in the classroom: A critical autoethnographic narrative chronicling the risks and rewards of a teacher and her students as they engage in the practice of a critical pedagogy. Unpublished doctoral dissertation, University of St. Thomas, St. Paul, Minnesota.

Hull, G. (1993). Critical literacy and beyond: Lessons learned from students and workers in a vocational program and on the job. Anthropology and Education Quarterly, 24, 308-317.

Jarvis, R. (1996). Practicing at praxis: Doing critical, feminist pedagogy. Retrieved from http: //coe.west.asu.edu/students/bjarvis/96-598/4cs.htm

Jensen, B. B. (2002). Knowledge, action and pro-environmental behaviour. Environmental Education Research, 8(3), 325-334.

Kanpol, B. (1999). Critical pedagogy: An introduction ( $2^{\text {nd }}$ ed.). Westport, CT: Bergin \& Garvey.

Keesing-Styles, L. (2000). An ecological approach to practicum assessment. International Journal of Early Childhood Education, 5, 71-81.

Keesing-Styles, L. (2000). An ecological approach to practicum assessment. International Journal of Early Childhood Education, 5, 71-81.

Kincheloe, J. L. (2004). Critical pedagogy. New York, NY: Peter Lang.

Kolmuss, A., \& Agyeman, J. (2002). Mind the gap: Why do people act environmentally and what are the barriers to pro-environmental behavior? Environmental Education Research, 8(3), 239-260.

Lather, P. (1991). Getting smart: Feminist research and pedagogy within the postmodern. New York, NY: Routledge.

Luke, C. (1992). Feminist politics in radical pedagogy. In C. Luke \& J. Gore (Eds.), Feminisms and critical pedagogy (pp. 25-53). New York, NY: Routledge.

Lusted, D. (1986). Why pedagogy? Screen, 27, 2-14.

Lyman, F. (1981). The responsive classroom discussion: The inclusion of all students. Mainstreaming Digest. College Park, MD: University of Maryland College of Education. 
Macdonald, D., \& Brooker, R. (1999). Articulating a critical pedagogy in physical education teacher education. Journal of Sport Pedagogy, 5(1), 51-63.

McIntosh, P. (1989). White privilege: Unpacking the invisible backpack. Peace and Freedom, July/August.

McKeachie, W. J., Pintrich, P. R., Lin, Y. G., Smith, D. A., \& Sharma, R. (2000). Teaching and learning in the college classroom: A review of the research literature (2nd ed.). Ann Arbor, MI: University of Michigan.

McLaren, P. (2000). Paulo Freire’s pedagogy of possibility. In S. Steiner, H. M. Krank, P. McLaren, \& R. E. Bahruth (Eds.), Freirean pedagogy, praxis and possibilities: Projects for the new millennium (pp. 121). New York, NY: Falmer Press.

McLaren, P. (2003). Life in schools: An introduction to critical pedagogy in the foundation of education: Boston, MA: Allyn \& Bacon.

McLaren, P., \& Farahmandpur, R. (1999). Critical multiculturalism and globalization: Some implications for a politics of resistance. Journal of Curriculum Theorizing, 15(3), 27-46.

McLaren, P., \& Houston, D. (2004). Revolutionary ecologies: Ecosocialism and critical pedagogy. Educational Studies, 36(1), 27-45.

Meyers, C., \& Jones, T. (1993). Promoting active learning. San Francisco, CA: Jossey-Bass.

Mun Wah, L. (Producer/Director). (1994). The colour of fear [Motion picture]. United States: Stir Fry Seminars.

Norton-Meier, L. (2002). Toward a critical pedagogy of popular culture: Literacy development among urban youth. Journal of Adolescent and Adult Literacy, 46(1).

O’Donoughue, R. \& Lotz-Sisitka, H. (2002). Some insights on the gap. Environmental Education Research, 8(3), 261-270.

Prilleltensky, I. (2001). Value-based praxis in community psychology: Moving toward social justice and social action. American Journal of Community Psychology, 29(5), 747-778.

Reinharz, S. (1992). Feminist methods in social research. New York, NY: Oxford University Press.

Ruiz, B. M., \& Fernandez-Balboa, J. M. (2005). Physical education teacher educators' personal perspectives regarding their practice of critical pedagogy. Journal of Teaching in Physical Education, 24(3), 243-264.

Russell, C. (1999). Problematizing nature experience in environmental education: The interrelationship of experience and story. Journal of Experiential Education, 22(3), 123-128, 137.

Scott, J., Buchanan, J., \& Haigh, N. (1997). Reflections on student-centered learning in a large class setting. British Journal of Educational Technology, 28(1), 19-30.

Shor, I. (1992). Empowering education: Critical teaching for social change. Chicago, IL: University of Chicago Press.

Shor, I. (1996). When students have power: Negotiating authority in a critical pedagogy. Chicago, IL: The University of Chicago Press.

Shor, I., \& Pari, C. (2000). Education is politics: Critical teaching across differences, postsecondary. Portsmouth, NH: Boynton/Cook.

Shrewsbury, C. M. (1987). What is feminist pedagogy? Women's Studies Quarterly, 15(3 \& 4), 6-14.

Simons, L., \& Cleary, B. (2005). Student and community perception of the "value added" for servicelearning. Journal of Experiential Education, 28(2), 164-188.

Sweet, S. (1998). Practicing radical pedagogy: Balancing ideals with institutional constraints. Teaching Sociology, 26, 100-111.

Tilemma, H. H. (2003). Integrating developmental assessment with student-directed instruction: A case in vocational education in the Netherlands. Journal of Vocational Education and Training, 55(1), 113127.

Van Manen, M. (1999). The language of pedagogy and the primacy of student experience. In J. Loughran (Ed.), Researching teaching: Methodologies and practices for understanding pedagogy (pp. 13-27). London: Falmer.

Weiler, K. (Ed.). (2001). Feminist engagements: Reading, resisting, and revisioning male theorist in education and cultural studies. New York, NY: Routledge.

Wink, J. (2005). Critical pedagogy: Notes from the real world ( $3^{\text {rd }}$ ed.). Boston, MA: Allyn and Bacon. 